\title{
FuZzy Logic BASEd TEACHING/LEARNing OF A Foreign LANGUAGE IN Multilingual Situations
}

\author{
Sweta SINHA \\ Indian Institute of Technology Patna \\ apna1982@gmail.com
}

\begin{abstract}
The concept of Fuzzy Logic (FL) has gained momentum in areas of artificial intelligence and allied researches because of its absolute ability to present efficient solutions to real life problems. Contrary to the paradigmatic approach to the solutions of being either absolutely true or false [0 or 1 ] the fuzzy sets provide a range of possible outputs with error prone inputs which are vague and inaccurate using linguistic objects instead of mere mathematical numbers. A multilingual situation poses a similar challenge for a language teacher/learner where languages exist in continuum. Learners with heavy mother tongue influence tend to use their natural languages instinctively in a way that can create their own fuzzy rules to encounter the situation of being taught an entirely new language. A typical Indian language classroom is highly multilingual where scope of errors is numerous though they are ignored. This leads to stress both for the teachers as well as the learners making the classroom ambience more mechanistic than human. To combat such situations FL based Three-Phase Model of language teaching has been proposed which derives its basis on the presumption that the language instructor is aware of general rules of linguistics. An empirical longitudinal study on 150 undergraduate technical students designed on the proposed framework has been conducted to establish the efficiency and the success of the model. Observing language pedagogy through the lens of fuzzy logic and fuzzy thinking will not only make the classroom more real-like but it will also tap the pre-existing linguistic knowledge of the learners. Language interference will be more of a resource than a challenge.
\end{abstract}

Keywords: Fuzzy Logic; FLT; multilingualism; language teaching; language pedagogy

\section{Povzetek}

Koncept mehke logike je zaradi svoje popolne zmožnosti podati učinkovito rešitev k problemom vsakdanjega življenja najprej pritegnil pozornost s področij, kot je na primer umetna inteligenca. $V$ nasprotju s paradigmatičnim pristopom navadne logike, kjer so rešitve lahko le absolutno pravilne in absolutno nepravilne [0 ali 1], mehka logika dovoljuje tudi vmesne vrednosti in torej opisno dovoljuje delno pravilnost. Večjezikovne situacije, kjer je meja med jeziki ni jasna temveč prehodna, predstavljajo za učitelja in učenca izziv, ki ga lahko predstavimo z mehko logiko. Učenci tujega jezika z močnim naglasom, ki je posledica vpliva maternega jezika, običajno jezik uporabljajo na način, da ob učenju tujega jezika ustvarijo svojevrstna mehka pravila. Tipična indijska jezikovna učilnica je običajno polna učencev iz različnih jezikovnih okolij, zato je tudi obseg napak zelo velik. Kljub temu,

Acta Linguistica Asiatica, 7(2), 2017.

ISSN: 2232-3317, http://revije.ff.uni-lj.si/ala/

DOI: 10.4312/ala.7.2.71-84 
da so številne napake namenoma večkrat spregledane, to predstavlja velik stres tako za učitelje kot učence in hkrati naredi učno okolje bolj mehansko kot človeško. Da bi preprečili takšna stanja, je bil vpeljan tristopenjski model jezikovnega učenja pri učenju tujega jezika. Model izhaja iz osnovne ideje, da se jezikovni učitelj zaveda osnovnih pravil v jezikoslovju. Longitudinalna empirična raziskava na 150 dodiplomskih študentih tehničnih smeri je bila izpeljana z namenom prikazati učinkovitost in uspešnost omenjenega modela. Opazovanje in opis jezikovnega poučevanja skozi prizmo mehke logike prikaže učno situacijo $v$ veliko bolj naravni luči, hkrati pa se loti jezikovnega predznanja učencev s popolnoma drugačnim pristopom; vpliv maternega jezika na usvajanje tujega jezika deluje kot sredstvo in ne motnja pri učenju tujega jezika.

Ključne besede: mehka logika; učenje tujega jezika; večjezičnost; poučevanje jezikov; jezikovna pedagogika

\section{Introduction}

Alice Kaplan's 1993 evocative account of her own love story with learning and teaching French reminds us that not all language learning is doomed (also in Lee, 1995, Chapter 8). Kaplan is blunt about the difficult task of being a language teacher: '[L]anguage teachers are always in search of the full proof method that will work for any living language and will make people perfectly at home in their acquired tongue' (Lee, 1995, p. 130). She has gone beyond the lure of method having seen its infinite regress where methods change completely in no time. (Davies, 2007)

From the forties on, people looked at linguists to revolutionize language teaching where 'labs' were made the prerequisite and the teaching was assesses based on scientific data and results. In the late 1950s Chomsky's hypothesis of language acquisition device and critical period did no good to the practice of language teaching as the teachers could not hope to reproduce childhood as a model for second-language learning. (Davies, 2007)

In the meantime rapid evolution in the field of technology transformed language pedagogy as well as perspectives on discourse. This transformation brought the language instructors face to face with advanced technological facilities that could be used to the advantage of the learner as well as the instructor. Despite this, technology based language teaching has undergone various changes and a perfect method to teach a foreign language is still far from reality. Kaplan addresses this issue when she suggests that: 'Language teaching methods make for a tale of enthusiasm and skepticism, hope and hope dashed. Every once in a while someone comes along and promises a new language method...... Whatever the method, only desire can make a student learn a language, desire and necessity' (Davies, 2007, p. 131). An important point to be taken from her suggestion is the need of desire among the learners. While devising methodologies it is very important to ignite such desire in learners and to keep the desire alive till the process is completed. 
With this kind of background the case of a multilingual classroom appears to be both challenging as well as resourceful. Multiple first languages interfere at varying degrees in a language classroom. Despite this, the anxiety in a typical ELT classroom cannot be ignored. From devising technology intensive techniques to the formation of differential learner groups (Sinha, 2016), ELT has come a long way. The very fact that ELT has emerged as a hugely researched area in the last fifty years justifies its increasing demand in the globalized world of today. One of the most fundamental causes that trigger anxiety in human behavior is the compulsion to perform in an artificial environment which takes one out of his/her comfort zone. The chief objective of this research paper is to propose a pedagogical model that can convert language interference' into 'language resource' in a multilingual classroom setting. The central idea of proposing this methodology is to tap the pre existing linguistic knowledge among the learners through an approach that is based on the concept of Fuzzy Logic.

\section{From Logic to Fuzzy Logic: The evolution}

One of the most relevant features that define us as human beings is that of possessing the capability to reason. Traditionally the science of reasoning has been deductive logic. But the idea of vagueness too has influenced the philosophical debate since ancient times. Thus, Aristotle highlighted the philosophical dimension of the formal study of vagueness with discussions on free will. Teaching of logic has formed part of mainstream education system for many years, fuzzy logic is a more recent development. Since 1965 (Zadeh, 1965) it has garnered increasing credibility and dissemination. Institutionally, formal logic is taught in the schools of Philosophy, Mathematics and more recently in Computer Science. But crisp reasoning has its own limitations. But, the adoption of Fuzzy Logic in the school of thought has been revolutionary. It has not remained mere theory; on the contrary, it has given rise to manufactured products, of industrial and domestic use. Therefore, according to (Sobrino, 2013) it is a theory that has received its own technology. It is not only a scientific matter but also a tool with which to do things; i.e. an applied logic. It deals with common sense reasoning; i.e. approximate reasoning (Zadeh, 1974). While crisp arguments are characteristics of mature stages of our cognitive development, individuals come across common argumentation from childhood (Beth \& Piaget, 1961) which explains the anxiety less comprehension of similar situations in adulthood.

\section{Fuzzyfication of learning}

Students' cognition utilizes in general concepts that are inherently graded and therefore fuzzy. Fuzzy Logic is much closer in spirit to human thinking as a natural language. The adjective 'fuzzy' gained wide popularity at least in two different 
prominent media: reporting and advertising. The scientific dissemination of fuzzy logic has been encouraged by the robustness of is solutions and the ease of management. This system has four principle components; a fuzzyfication interface, a knowledge base, decision making mechanism and a defuzzyfication. The target of this paper is to advocate the adoption of fuzzy logic based approach and propose a model that could be adopted in each particular case in order to represent the process of the corresponding didactic situation.

The concept of learning is fundamental to the study of human cognitive action; but while everyone knows in general what learning is, the understanding of its nature has proved to be complicated. This basically happens because it is very difficult for someone to understand the way in which the human mind works, and therefore to describe the mechanisms of the acquisition of knowledge of the individual. As (Voskoglou, 2011) states the problem is getting even harder by taking into consideration the fact that these mechanism, although they appear to have some common general characteristics, actually they differ in details from person to person.

Voss (1987) adopted an argument raised much earlier by (Ferguson, 1956) and others that learning is a specific case of the general class of transfer of knowledge and therefore any instance of learning involves the use of already existing knowledge. Accordingly learning basically consists of a continuous sequence of problem-solving activities, in which the input information is processed as per the existing knowledge, with the solution occurring when the input is appropriately interpreted. Learning, therefore, consists of developing an appropriate number of interpretations and generalizing them to a variety of situations.

\section{Fuzzy Logic: Theoretical point of view}

Human beings reach a decision through a thinking process whereas expert systems make decisions through the inference process. Human beings make decisions in fuzzy environments using fuzzy variables. This uniqueness of human cognition and decision making has been adapted in various technological inventions and applications. As (Trillas \& Guadarrama, 2010) write that this theory is based on the intuition of people materialized in the design of each fuzzy set. Thus, it is obvious that the relevance of Fuzzy Logic (FL) comes with technological developments (Mamdani, 1974; Sugeno \& Murofushi, 1991) but the essence of FL goes further of its applications. In 1965 Zadeh introduced the concept of Fuzzy Set (Zadeh, 1965), this fact enlarges the definition of a Classical Set, it allows the existence of elements that are not necessary in the set or outside, and elements can belong to the set with a degree. He tries to provide a more humane approach to science taking the analysis from the realms of mathematical figures to linguistic variables. To put it simply, human mind operates on vagueness and approximation most of the times unless the task demands some sort of expertise. This 
vagueness/approximation are what that lends a level of comfort to human behavioral pattern. Real life situations are not either Yes or No [1 or 0]. The situations range from 0 to 1 where arguments can neither be completely true nor completely false; partially true but not false and partially false but not true are also the possibilities. The FL has been tried by the westerners as a probabilistic logic, endless values of truth among the value of void probability 0 and the value of probability! (Spagnolo, 2003)

More so specifically the set theories have been made popular in basic education ender the name of Modern or Abstract Mathematics (Garcia-Honrado, 2013). Once setting the axioms, Mathematical knowledge could be built. This fact goes together with Piaget's Constructivism (Piaget, 1962). Following the ideals of Constructivism and the relation with intuition, Fuzzy Set Theory could appear naturally, since its aim is to formalize people intuitions and the theory is built over strong but, under mathematical point of view, not very difficult bases.

The main idea here is to introduce propositions that are not actually true or false but to make logic closer to reality, capable to translate human perceptions and languages; therefore, it could be considered to be more related to humans' intuition than Classical logic, having the same solid mathematical bases.

\section{Fuzzy logic and Language Teaching/ Learning}

A language has four primary skills listening, speaking, reading and writing (LSRW) and in a typical language classroom the learners are evaluated on the basis of their performance in these skills. The tests are output oriented focusing solely on the correctness/ incorrectness of the responses ignoring the perception or the psycholinguistic processes occurring in the mind prior to the generation of the responses.

These tests grade a learner either in PASS or FAIL category but the knowledge of a language, more so natural language must have a continuum in gradation. A learner can only be more/less bilingual/multilingual in comparison to others. If asked a question in the target language (TL), the learner might fail to respond in TL but may respond correctly in mother tongue (MT). Such learners should not be failed simply because he/she is able to correlate the concepts in TL and MT.

\subsection{Bivalence-Polyvalence debate}

The advent of science has affected our perception of the world around us to a great deal and this has fuelled the debate between the schools of bivalence and polyvalence. 
Table 1: Bivalence-Polyvalence Dichotomy

\begin{tabular}{cc}
\hline Bivalence & Polyvalence \\
\hline A not A & A and not A \\
Exact & Partial \\
All or Nothing & To a certain exact \\
Boolean system & Neural Networks \\
Artificial language & Natural Language \\
Bits & Fits (Fuzzy Units) \\
\hline
\end{tabular}

The knowledge representation of a natural language is polyvalent. Response generated from the learners should not be judged merely for the validity of truth but it should be considered from the angle of the degree of the validity of truth.

\section{Representation of Fuzzy sets for Natural languages: the drawback and the way ahead}

According to (Challa, 2015) in general there are two approaches for constructing fuzzy models:

a. identification of fuzzy modeling, using input-output data and

b. derivation from given non-linear system equations.

The chief purpose of this section is to adopt the aforesaid approach and propose a model that can be adopted in language teaching/ learning classrooms. In order to understand the avenue for the application of fuzzy logic in language pedagogy classes and its subsequent implications it is imperative that we take two distinct cases for general understanding and argument thereafter. Let us consider two typical cases and see how can this be analyzed where one learner $\left(L_{1}\right)$ is a monolingual proficient in a language $X$ and another learner $\left(L_{2}\right)$ is bilingual (proficient in natural languages $X$ and $Y)$. In a language classroom $L_{1}$ and $L_{2}$ will be exposed to a new natural language $M$. This situation is typical of India as well as most of South Asia and South East Asia where a speaker of an indigenous language is exposed to a more popular second language but then is expected to be proficient in a third language for the purposes of education and commerce.

If ' $x$ ' is the acquired linguistic competence of $X$ for $L_{1}$ and if she/he has completed being instructed for $M$ then the advancement in the cumulative competence $\left(\mathrm{CC}_{\mathrm{L} 1}\right)$ can be represented mathematically as:

$$
\mathrm{CC}_{\mathrm{L} 1}=\mathrm{x}+\mathrm{m}
$$

Similarly, for $L_{2}$ who has a previously acquired competence in $X$ and $Y$ and has been instructed for $\mathrm{M}$, the representation can be:

$$
\mathrm{CC}_{\mathrm{L} 2}=\mathrm{x}+\mathrm{y}+\mathrm{m}
$$


Here $\mathrm{CC}_{\mathrm{L} 2}$ is the cumulative competence of Learner $\mathrm{L}_{2}$ in languages $\mathrm{X}, \mathrm{Y}$ and $\mathrm{M}$. So far, there does not seem to be any contention. The mathematical equations presented above are indicative of the advancement on the cumulative competence of the speakers $L_{1}$ and $L_{2}$. The major drawback lies with the methodology of language teaching which compartmentalizes one natural language from another. The language instructors do not attempt sufficiently to tap on the previously acquired linguistic information of $(\mathrm{X})$ and $(\mathrm{X}$ and $\mathrm{Y})$ for the two learners respectively who are being exposed to (M). Consequently it leads to a situation that can be represented as in Figure 1 be

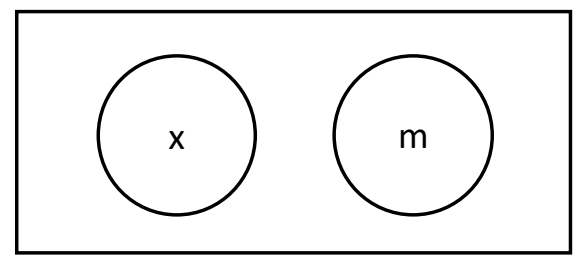

Figure 1: L1 case where natural languages are compartmentalized during language teaching/ learning process

Similarly, for $L_{2}$ the representation can be somewhat similar to Figure 2 below.

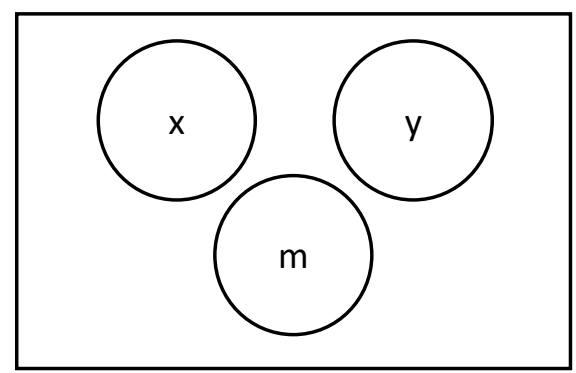

Figure 2: L2 case where natural languages are compartmentalized during language teaching/ learning process

The natural languages should not be seen in isolation as in Figures 1 and 2 above. Natural languages have many linguistic similarities with respect to sounds, word categories, word order or semantic interpretation of referents to name a few. The similarities may count from few to many but two languages cannot be absolutely different from one another at all the linguistic levels. The languages have certain very general structural properties in common ( $\mathrm{O}^{\prime} \mathrm{Grady}$ et al., 2009) and some distinctive features which add to their uniqueness.

The chief argument here is to focus on the overlapping features of the concerned languages so that appropriate model can be proposed to make teaching/ learning interesting and familiar. If this argument is adapted then figures 1 and 2 need to be revised as figures 3 and 4 respectively. 


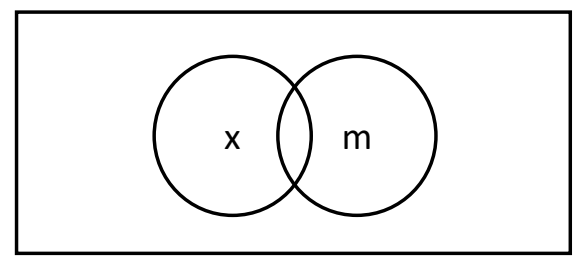

Figure 3: $L_{1}$ case where natural languages are overlapping

The cumulative competence of $L_{1}$ in languages $X$ and $M$ can be expressed as:

$$
\mathrm{CCL}_{1}=\mathrm{x} \cup \mathrm{m}
$$

and the competence developed based on the overlapping features of the two natural languages can be expresses as:

$$
\mathrm{CCL}_{1}=\mathrm{x} \cap \mathrm{m}
$$

Similarly for the second case $L_{2}$ the revised figure would be

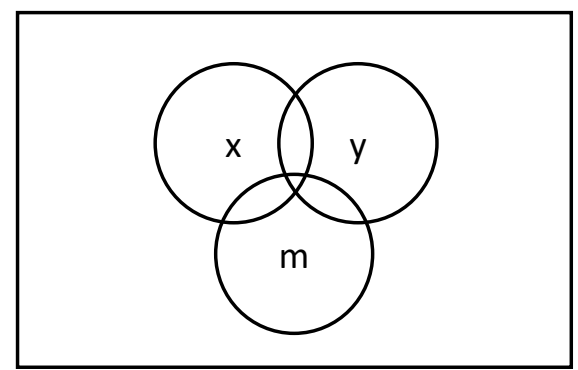

Figure 4: $L_{2}$ case where natural languages are overlapping

The cumulative competence of $L_{2}$ in languages $X, Y$ and $M$ can be expressed as:

$$
\mathrm{CCL}_{1}=\mathrm{x} \cup \mathrm{y} \cup \mathrm{m}
$$

and the competence developed based on the overlapping features of the three natural languages can be expresses as:

$$
\mathrm{CCL}_{1}=\mathrm{x} \cap \mathrm{y} \cap \mathrm{m}
$$

If the language instructor attempts to work on finding out the linguistic features lying in the $(x \cap m)$ region then the task of instructing $M$ reduces from ' $m$ ' to ' $(x \cup m)-x$ ' as can be seen in Fig. 3. Similarly, for $L_{2}$ as in Figure. 4 the quantum of instruction for $M$ changes from ' $m$ ' to ' $(x \cup y \cup m)$ - $(x \cup y)$ '. this will not only reduce the timeframe involved in accomplishing the task of instructing a new language but it will also reduce anxiety on the part of the learners who will start on a more familiar note in the classroom, ie. the overlapping features of the previously acquired language and a new language. However this argument does not come without certain challenges. One major 
challenge lies with the instructors who would be expected to do a check on the linguistic background of the students before commencing with the instructions in a new language. A thorough database regarding the languages known by the learners will have to be maintained which can be initially time consuming requiring proper analysis and framing appropriate approaches with respect to the language known by the prospective learners. The need to form smaller groups may also rise in all probability but once these challenges are successfully handled the overall process of teaching/ learning will become immensely efficient and anxiety free. The following section is an attempt to propose a framework to combat the aforementioned challenge.

\section{Proposed Three-Phase Model (TPM) for instructors}

The entire process of teaching language can be divided into three phases each with a distinct objective and plan of action. The three phases are:

\section{a. Phase I or the Pre-Instructional Phase}

In this phase, the main objective of the instructor is to find out the degree of similarity and difference between the first language/ second language and the target language. In order to accomplish this, the instructor needs to know about the linguistic background of each of the student and then compare and contrast the languages.

\section{b. Phase II or the Instructional Phase}

Tabulation of such similarities and differences make Phase I of TPM. Once done the instructor is expected to draw a correlation between the languages at major linguistic levels like Phonology, Morphology, Syntax and Semantics. The chief purpose here is to make the teaching/ learning practice more conscious and human. Once this stage is reached the first stage of Phase II of the model is accomplished. According to Sinha (2016) the methodology of graded evaluation with respect to perception, processing and production is employed which has its basis in FL. Put simply; the boundaries between two levels of competence are fuzzyfied.

\section{c. Phase III or the Post-Instructional Phase}

Lastly, the instructors provide a feedback on the overall performance of the learners using linguistic variables chiefly. This is the phase III of the model. In a nutshell, the entire model is based on the identification of Input-Output data. The input by way of instruction is correlated with the output. The correlation may not be one-to-one. So, essentially, the correlation will be more on the lines of the natural process of language learning and the overall feedback would be the responsibility of the instructor who would base his evaluation model on $\mathrm{FL}$ 


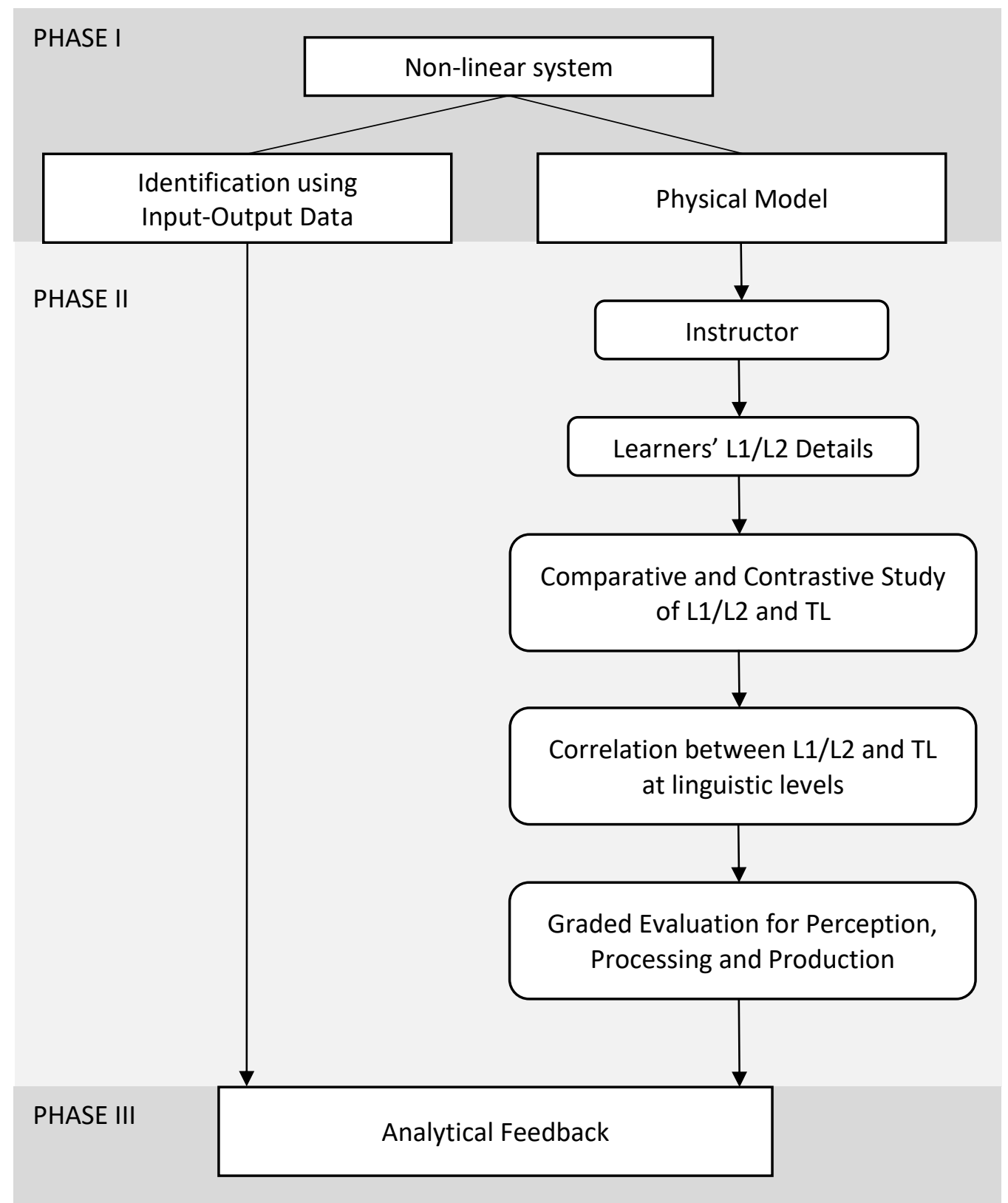

Figure 5: Proposed Three-Phase Model (TPM)

\section{Empirical Study to test the validity of TPM}

In a multilingual country like India, devising a standard test battery for language skill evaluation is tough because of varied factors like: socio-economic background of the speakers, linguistic background, and educational background of the speaker as well as the linguistic background of her/his immediate family members, political environment and power position of various languages. These issues need to be accounted for in a 
more progressive manner as Davies (2007) suggests that language teaching should be 'context-sensitive'. There is a major flaw with the existing system of language skills development classes/ training classes currently operative in India. There are basically two modes of language training: ILT (Instructor Led Training in which the instructor is the centre) and CBT (Computer Based Training which are primarily self-help exercises on PC). Since the learners came from different backgrounds so their degree of proficiency in the four (LSRW) skills might differ and the generalized approach of training does not consider individual difference with respect to the skills. Psychological factors (Tanveer, 2007) have been found to retard the process of language learning and anxiety being a major player. It acts as a major obstacle in second language learning and the research findings suggest that there is a direct relation between anxiety and problems in second language communication. As a result, public speaking becomes anxiety provoking. Therefore, the proposed model was found suitable to be implemented in the language instruction classroom.

The data was collected twice, firstly, before the model was implemented (as in A below) and secondly, five months after the model was implemented (as in B below).

\section{Data Collection and analysis}

A class size of 150 B.Tech students (between the age group of 18 to 20 years) chiefly belonging to Bihar, Himachal Pradesh and Rajasthan (Indian states with different state languages) were considered for a longitudinal study over a period of five months. They were marked on a scale of 10 based on four language skills (LSRW). Table 2 below shows their performance before the proposed model was introduced. Depending on the performance, the students were grouped into five categories: outstanding, very good, good, average and poor.

Table 2: Parameter for Data Analysis

\begin{tabular}{cccc}
\hline Group & Category & Score Range & Score Per Skill \\
\hline I & Outstanding & $36-40$ & 9 or $<$ \\
II & Very good & $32-35$ & 8 \\
III & Good & $28-31$ & 7 \\
IV & Average & $20-27$ & 5 \\
V & Poor & $1-19$ & 0 \\
\hline
\end{tabular}

Initially majority of the students fell in the categories of poor and average based on their performance as shown in Figure 3. 


\section{Performance of Language Skill}

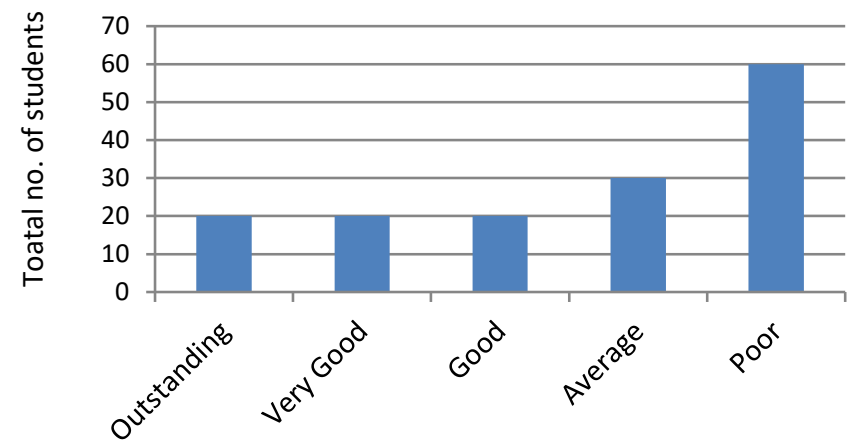

Figure 6: Before introducing TPM based instruction

Second set of data was collected after five months of introduction of the proposed pedagogical model in the classroom. The performance was evaluated on a scale of 10 where for each language error (0.5) mark was deducted that excluded punctuation errors. After the second phase of analysis it was noticed that there was a marked shift in the category of students from poor to average and average to good in the performance of language skills as shown in the following figure.

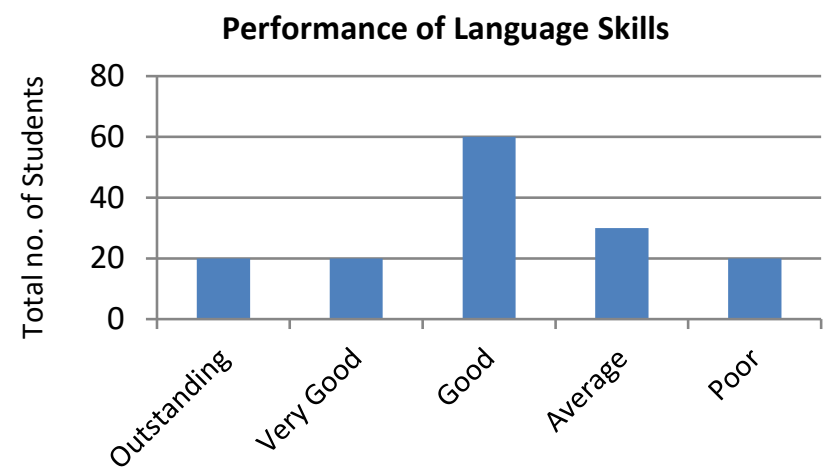

Figure 7: After introducing TPM based instruction

\section{Conclusion}

Spagnolo (2003) in his discussion on the relationship of natural language and the understanding of mathematics tries to answer a few very pertinent questions. He tries to figure out the contribution of natural language in the development of reasoning as well as to account for the impact of multicultural situations of teaching/learning of mathematics. Basin my argument on Spagnolo's research questions, it is very apt to focus on the fuzzyness of the relationship between two natural languages. 
The interpretation of the phenomenon of learning/teaching of a language is quite complicated. The interpretative tools have to be kept in mind and according to Spagnolo "the structure of natural language" is one such tool. In the process of learning/ teaching in multicultural/ multilingual situation a very important role is played by the fact that it has to exist a moment in which there are moments of socialization of the decisive strategies of a situation/ problem in the classroom.

This paper tries to advocate the adoption of a very revolutionary approach of Fuzzy Logic in the teaching/ learning of languages. The main idea that is being conveyed through this paper is to teach language in a continuum. Natural languages have various similarities with each other so framing pedagogies around them has a strong possibility to make the teaching/ learning process anxiety free. Another point that has been raised subtly in this paper is the awareness of linguistic levels of natural languages among the instructors. If the instructors have an adequate exposure of Linguistics as a subject then the adoption of the proposed Three-Phase Model (TPM) would not only ease the task of language teaching but it would also increase the overall efficiency. Before concluding the paper it must be reiterated that FL based system operates like a human describing the results in linguistic terms which are more humane, fair and objective. It is aimed to provide a reasonable and flexible evaluation system along with making the entire process of teaching/ learning prejudice free and bias free.

\section{References}

Beth, E. W., \& Piaget, J. (1966). Mathematical epistemology and psychology. Dordrecht: D. Reidel. (First French ed., 1961).

Brown, H. D. (2001). Teaching by principles: An interactive approach to language pedagogy. Beijing: Foreign language Teaching and Research Press.

Challa, K. A. (2015). Fuzzy logic based approach for Computer Assisted English Learning in International Journal of Modern Engineering, 5(12), 66-70.

Davies, M., Hirschberg, J., Lye, J., Johnston, C., \& McDonald, I. (2007). Systematic Influences on Teaching Evaluation: The Case for Caution. Australian Economic Papers, 46(1).

Fergusson, G. (1956). On transfer and the abilities of man. Canadian Journal of Psychology, 10, 121- 131.

Garcia-Honrado, I. (2013). Reflections on the teaching of Fuzzy Logic. $8^{\text {th }}$ Conference of the European Society for Fuzzy Logic and Technology, 683-690.

Mamdani, E. (1974). Application of fuzzy algorithms for control of a simple dynamic plant. Proc. IEEE, 12, 1585-1588.

O'Grady, W., Dobrovolsky, M., \& Aronoff, M. (1989). Contemporary linguistics: An introduction. New York: St. Martin's Press.

Piaget, J. (1962). The Psychology of the Child. New York: Basic Books. 
Sinha, S. (2016). Differential approach to technology aided English language teaching: a case study in a multilingual setting. $18^{\text {th }}$ International Conference on Applied Linguistics and Foreign language teaching. Hong Kong.

Sobrino, A. (2013). Fuzzy Logic and Education: Teaching the Basics of Fuzzy logic through an Example (by Way of Cycling). Education Sciences, 3(2), 75-97.

Spagnolo, F. (2003). Fuzzy logic, fuzzy thinking and the teaching/learning of mathematics in multicultural situations. Proceedings International Conference on Mathematics Education into the $21^{\text {st }}$ Century (MEC21), (pp. 17-28). Brno.

Sugeno, M. \& Murofushi, T. (1991). Helicopter flight control based on fuzzy logic. Proc. $1^{\text {st }}$ International Fuzzy Engineering Symposium, (pp. 1120-1121). Yokohama, Japan.

Trillas, E., \& Guadarrama, S. (2010). Fuzzy representations need careful design. International Journal of General Systems, 39(3), 329-346.

Voskoglou, M. (2011). Fuzzy Logic and Uncertainty in Mathematics Education. International Journal of Applications of Fuzzy Sets, 13, 45-64.

Voss, J. F. (1987). Learning and transfer in subject learning: a problem solving model. International Journal of Educational Research, 11, 607-622.

Zadeh, L. A. (1965). Fuzzy Sets. Information and Control (8), 338-353.

Zadeh, L. A. (1974). Fuzzy Logic and its Application to Approximate Reasoning. IFIP Congress (pp. 591-594). Atockhol, Sweden. 